\title{
Malocclusion influence on balance and posture: a systematic review
}

\section{Influência da má oclusão no equilíbrio e postura: revisão sistemática}

\author{
Tatiane Garcia Stancker ${ }^{1}$, Andréia Cristina de Oliveira Silva', Hugo Pasin Neto², Cristiane Delgado Alves Rodrigues ${ }^{2}$
}

\begin{abstract}
Introduction: Malocclusion can be defined as an imbalance between the masticatory system and neuromuscular Temporomandibular joint. It is considered as a result of the sum of genetic, environmental and postural elements therefore of multifactorial origin. Objective: To review the existing literature if malocclusion influence in posture and balance of the subject. Methods: This is a systematic review, which searched up clinical studies, published between 2009 and 2014 in English, Portuguese and Spanish, in the databases SciELO, PubMed, Lilacs and Sience Direct, using the keywords malocclusion/posture and malocclusion/body balance. Studies were included that had to evaluate the posture and/or balance in patients with malocclusion, were excluded systematic reviews and studies that did not correspond to the proposed theme. Results: In addition to the articles found in all databases, the corpus generated by the literature consisted of 828 records; 13 of them responded to the proposed theme. About the selected literature, eight studies showed significant results regarding the relationship between malocclusion and posture, and two as malocclusion and body balance. Conclusion: it was concluded that malocclusion is associated with the posture of the changes, since the balance, only two studies presented this outcome and was in a considered positive for the worsening of static equilibrium, but with no clinical application, and another positive for improves dynamic balance.
\end{abstract}

Keywords: Occlusion, Posture, Body Balance.

\section{RESUMO}

Introdução: A má oclusão pode ser definida como um desequilíbrio entre o sistema mastigatório e neuromuscular da articulação Temporomandibular. É considerada como resultado da soma de elementos genéticos, ambientais e posturais, portanto de origem multifatorial. Objetivo: Revisar na literatura existente se a má oclusão influencia na postura e no equilíbrio do indivíduo. Métodos: Trata-se de uma revisão sitemática, onde buscaram-se estudos clínicos, publicados entre os anos de 2009 e 2014, nas línguas inglesa, portuguesa e espanhola, nos bancos de dados Scielo, Pubmed, Lilacs e Sience Direct, utilizando as palavras chaves má oclusão/postura e má oclusão/ equilíbrio. Foram inclusos os estudos que tinham como objetivo avaliar a postura e/ou o equilíbrio em indivíduos com má oclusão, sendo excluídos revisões sistemáticas e estudos que não correspondiam ao tema proposto. Resultados: Somando-se os artigos encontrados em todos os bancos de dados, o corpus gerado pelo levantamento bibliográfico consistiu de 828 registros; sendo que 13 responderam ao tema proposto. Sobre a literatura selecionada, oito estudos apresentaram resultados significativos quanto à relação entre má oclusão e a postura, e dois quanto a má oclusão e o equilíbrio corporal. Conclusão: conclui-se que má oclusão está associada a alterações da postura do indivíduo, já o equilíbrio, apenas dois estudos apresentaram este desfecho e foi em um considerado positivo para a piora do equilíbrio estático, porém sem aplicação clínica, e outro positivo para a melhora do equilíbrio dinâmico.

Palavras-chave: Oclusão Dentária, Postura, Equilíbrio Postural.

Corresponding Author: Andréia Cristina de Oliveira Silva. Rua Luiz Roque de Oliveira, 235, Zip Code: 18108-050, Sorocaba (SP), Brazil. Phone: (15) 9 9116 7653, (15) 3236 6573. E-mail: silva.acos@gmail.com

${ }^{1}$ Physical therapy student, Universidade de Sorocaba, Sorocaba, São Paulo, Brazil.

Full list of author information is available at the end of the article.

Financial support: None.

Submission date 24 July 2015; Acceptance date 5 October 2015; Online publication date 13 October 2015 


\section{INTRODUCTION}

Several factors may modify the body posture and balance, among these dental malocclusion has great relevance. ${ }^{(1)}$

The temporomandibular joint (TMJ), formed by the temporal and mandibular bone, is responsible for chewing, swallowing and speech. It is linked to cervical and scapular region by a common neuromuscular system, so your changes can affect mainly these regions. ${ }^{(2)}$

Furthermore, this joint is one of the components of the Stomatognathic System, responsible for the execution of joint tasks, thus including bone components (maxilla and mandible), soft tissue (salivary glands, nervous and vascular supply), muscle and dental arch. ${ }^{(3)}$

This complex masticatory device allows the union between the anterior muscle chains, with fixings starting from the jaw to the hyoid bone and the shoulder girdle structures, and later through the relationship of the jaw with the skull. ${ }^{(4)}$

When the upper arch contacts independent of the lower jaw position is called occlusion. It being part of the Stomatognathic system can directly influence the other functions of this system. Analyzing the occlusion can identify if the individual has physiological or pathological relationship between the dental arches, the latter being called malocclusion. ${ }^{\left({ }^{5}\right)}$

The malocclusion can be defined as an imbalance between the masticatory system and neuromuscular Temporomandibular joint. It is considered as a result of the sum of genetic, environmental and postural elements therefore of multifactorial origin. ${ }^{(6)}$

The occlusive disorders can occur in the three anatomical planes. Paying attention in the sagittal plane, we find three occlusion classes. The first, Class I, is the physiological relationship between the teeth, so that mandibular molar tooth means are positioned forward on the maxillary molars (normoclusion).

The Class II or overshot, occurs when the mandibular molar is subsequent to the maxillary molar, and can be subdivided into two types, differing by the position of incisors, it may be oriented to face having a front opening, generally associated with one lingual dysfunction (Class II, division 1); or driven back, usually associated with a supra-occlusion (Class II, Division 2). Finally, Class III are called prognathous, they present the anterior maxilla in relation to the upper jaw. ${ }^{(4)}$

In the Angle classification, we can find many other types of malocclusion in the literature, for example, the posterior crossbite consisting of an abnormal relationship in the lateral direction of one or more teeth of the maxillary, mandibular, or both, resulting in a disability performing the normal occlusion and open bite where there is a lack of contact between the incisors. ${ }^{(7,8)}$

It is known that the body balance is directly related to the cranial position on the cervical region and thus represent the position. The skull's center of gravity is located in the anterior region of the cervical spine and temporomandibular joints. Muscular structures of the head, neck and shoulder girdle are responsible for maintaining the standing position of the joint. Therefore any change in one of these structures can cause postural imbalance. ${ }^{(3)}$

Furthermore, the vestibular system to adjust the postural balance of the body, based on information from three principal sensors postural: feet, eyes and masticatory apparatus. Therefore, when one of the captors are unregulated, your information is affected, triggering a pathological posture. ${ }^{(4)}$

To Bricot ${ }^{4}$ individuals with Class II dysfunction suffer change in position of the head and shoulders, projecting them forward. The opposite occurs with prognathic individuals (Class III). This is due to the body's attempt to balance against the afferent issued by temporomandibular joint position.

Based on these, justified the deepening of the relationship of malocclusion with posture and body balance, because these being established clinical practice may act with more specificity in treatment. Therefore, this study is a systematic review and aims to review the existing literature malocclusion influence on posture and balance of the individual.

\section{METHODS}

The work consists of a systematic review carried out through the search of original articles in English, Portuguese and Spanish languages in the following databases: Scielo, Pubmed, Lilacs and Sience Direct. For search we used the keywords: malocclusion, posture and balance as well as their respective descriptors in English and Spanish and is willing to "malocclusion and posture" and "malocclusion and balance." They were evaluated studies published between 2009-2014, describing the relationship of malocclusion with posture and body balance. Clinical studies were included that had to evaluate the position and/or balance in patients with malocclusion, systematic reviews were excluded and studies that did not correspond to the proposed theme.

\section{RESULTS}

Of the 828 articles were selected 13 articles dealing with the proposed theme (Figure 1). 814 were excluded items, which had not among its objectives discuss the influence of malocclusion in balance and / or body posture. The results of each study are briefly described in Table 1.

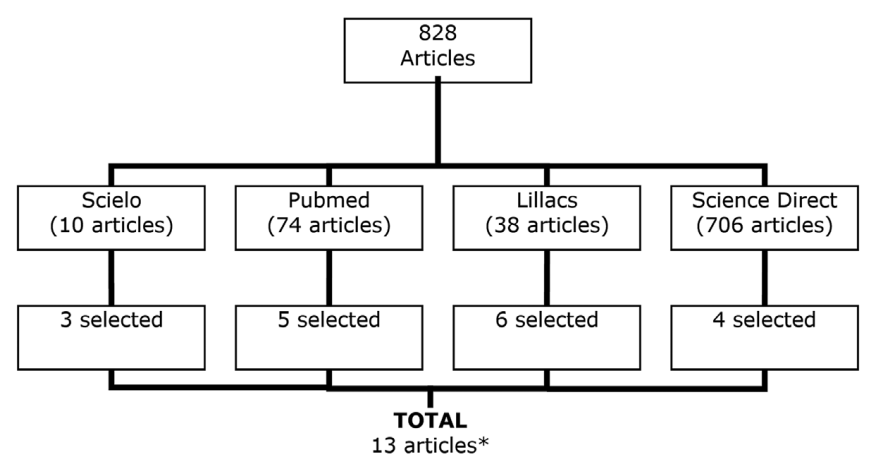

Figure 1. Flowchart of searches and selections in databases. *4 studies were found in more than one database. 
Table 1. Studies and main results.

\begin{tabular}{|c|c|c|c|c|}
\hline Year & Authors & Objective & Population (n) & Main results \\
\hline 2009 & Pérez et al..$^{(9)}$ & $\begin{array}{l}\text { To describe the changes in craniocervical posture } \\
\text { in a pediatric population with Class III after using } \\
\text { mentonera with lower acetate plate to raise the } \\
\text { bite. }\end{array}$ & 11 & There was no significant results. \\
\hline 2009 & Lopes et al. ${ }^{(10)}$ & $\begin{array}{l}\text { To dssess the posture of children with posterior } \\
\text { cross bite. }\end{array}$ & 41 & All children have postural changes. \\
\hline 2010 & Marşan et al..$^{(11)}$ & $\begin{array}{l}\text { To determine the variations of head posture and } \\
\text { hyoid bone position after surgical correction of } \\
\text { mandibular prognathism in adult patients with } \\
\text { Class III. }\end{array}$ & 42 & $\begin{array}{l}\text { Changing the position of the hyoid bone and } \\
\text { down language root immediately postoperatively. }\end{array}$ \\
\hline 2010 & Perinetti et al. ${ }^{(1)}$ & $\begin{array}{l}\text { To investigate whether malocclusion is related to } \\
\text { postural changes in young people. }\end{array}$ & 122 & $\begin{array}{l}\text { Few data were considered significant, including } \\
\text { the primary phase of teeth and malocclusion } \\
\text { classified as overbite shown to be associated with } \\
\text { the center of gravity changes measured by the } \\
\text { pressure pad. }\end{array}$ \\
\hline 2011 & Aldana et al..$^{(12)}$ & $\begin{array}{l}\text { To test the null hypothesis: "there is no } \\
\text { relationship between malocclusion and postural } \\
\text { changes of head and neck." }\end{array}$ & 116 & $\begin{array}{l}\text { Among the results were found associations } \\
\text { between anti-clockwise rotation skull with } \\
\text { Class III mandibular posterior rotation with } \\
\text { dolichofacial individuals * and Class II with the } \\
\text { tongue position at rest. }\end{array}$ \\
\hline 2011 & Perillo et al. ${ }^{(13)}$ & $\begin{array}{l}\text { To investigate the relationship between } \\
\text { malocclusion and Helkimo Index } \geq 5 \text { with postural } \\
\text { changes in children and young people. }\end{array}$ & 1178 & $\begin{array}{l}\text { The correlation between patients with } \\
\text { malocclusion and Helkimo Index } \geq 5 \text { with the } \\
\text { worst asymmetry trunk and better performance } \\
\text { in the Fukuda test was found. }\end{array}$ \\
\hline 2012 & García et al. ${ }^{(14)}$ & $\begin{array}{l}\text { To investigate the existence of significant } \\
\text { differences in cervical posture of teenagers with } \\
\text { different dental occlusion Classes. }\end{array}$ & 28 & $\begin{array}{l}\text { There was a significant relationship between } \\
\text { cervical curvature and the distance from } \mathrm{C} 0-\mathrm{C} 1 \\
\text { with skeletal occlusal Classes. }\end{array}$ \\
\hline 2012 & Deda et al. ${ }^{(15)}$ & $\begin{array}{l}\text { Comparing a group of patients with malocclusion } \\
\text { with a control group and investigate whether } \\
\text { there are differences between head posture. }\end{array}$ & 25 & $\begin{array}{l}\text { Regarding the evaluation by photogrammetry, } \\
\text { there was no significant difference between } \\
\text { groups. Clinical inspection has achieved } \\
\text { significant results, where } 100 \% \text { of Class II subjects } \\
\text { had forward head and } 73.3 \% \text { in the control group, } \\
\text { showed neutral head position. }\end{array}$ \\
\hline 2012 & Lippold et al. ${ }^{(16)}$ & $\begin{array}{l}\text { To assess the effect of early orthodontic treatment } \\
\text { for unilateral posterior cross bite in deciduous and } \\
\text { mixed dentition, using orthopedic parameters. }\end{array}$ & 77 & There was no significant results. \\
\hline 2013 & Silvestrini-Biavati et al. ${ }^{(17)}$ & $\begin{array}{l}\text { To investigate the incidence of malocclusion with } \\
\text { ocular convergence and postural disorders }\end{array}$ & 605 & $\begin{array}{l}93.8 \text { to } 94.2 \% \text { of the entire sample, consisting } \\
\text { of individuals with and without malocclusion } \\
\text { presented symmetry of the lower limbs. For } \\
\text { gait disturbance, it was not found significant } \\
\text { differences between the occlusal Classes. }\end{array}$ \\
\hline 2013 & Kumar e Pentapati ${ }^{(18)}$ & $\begin{array}{l}\text { To assess the position of the head of patients } \\
\text { undergoing treatment with headgear braces and } \\
\text { compare with a group without intervention. }\end{array}$ & 55 & There was no significant results. \\
\hline 2014 & $\begin{array}{l}\text { Kim, Sarauw e } \\
\text { Sonnesen }{ }^{(19)}\end{array}$ & $\begin{array}{l}\text { To relate the head posture and cervical spine } \\
\text { with the cranial morphology of children and } \\
\text { adolescents with open bite dentoalveolar and } \\
\text { skeletal. }\end{array}$ & 111 & $\begin{array}{l}\text { Individuals with skeletal type of open bite } \\
\text { present greater extent of head relative to the } \\
\text { dentoalveolar group. }\end{array}$ \\
\hline 2014 & Kim et al. ${ }^{(20)}$ & $\begin{array}{l}\text { To assess the posture of the head and pharyngeal } \\
\text { airway after bimaxillary surgery in prognathic } \\
\text { patients. }\end{array}$ & 25 & $\begin{array}{l}\text { The cranio-cervical angle increased significantly } \\
\text { after } 6 \text { months of surgery while the total volume } \\
\text { of the nasal pharynx and airways and oro- } \\
\text { pharyngeal decreased. There was no significance } \\
\text { for the relationship between head posture and } \\
\text { the total volume of airways. }\end{array}$ \\
\hline
\end{tabular}

Source: Author's Development. *Dólico Facial - Indivíduo com face longa (apresenta cabeça ovalada, comprida e estreita no sentido horizontal), com certa tendência à retrusão mandibular ${ }^{(21)}$. 


\section{DISCUSSION}

Among the selected studies, two evaluated the posture of the head and neck before and after surgery for prognathism correction. Marsan et al. ${ }^{(11)}$ conducted a study to determine the changes in head posture and position of the hyoid bone after mandibular osteotomy in 42 Turkish adult patients with Class III. The cephalometric analysis revealed that the hyoid bone moved inferiorly and then after surgery, which corresponds to cervical flexion and in the long term, shown repositioning onto the hyoid bone and compensatory decrease in craniocervical angle (corresponding to an extension movement of the head).

Since Kim et al. ${ }^{(20)}$ reported changes in cranio-cervical angle prognats bimaxilar patients undergoing surgery after six months. The results obtained before and after the surgical procedure through three-dimensional image showed a significant increase in the cranio-cervical angle, increasing the bending head, which suggests a new adaptation to the new body front jaw positioning. In addition, evaluating the total volume of airways, there was a decrease in the total volume pharyngeal, but without statistical significance.

Thus, when comparing the two studies, we observe the consistency of their results, which show that surgical correction of mandibular prognathism results in postural changes, mainly presented by cervical flexion, observed by the significant increase in the craniocervical angle. The repositioning of the hyoid bone and cranio-cervical angle shown in Marsan et al. ${ }^{(11)}$ study can be explained by the last interval of data collection which was approximately 4.2 years after surgery, while the study by Kim et al. ${ }^{(20)}$ had the interval of six months after the procedure.

Another major theme was the effect of orthodontic treatment on the individual's position, discussed by three different studies. Perez et al9, described by means of lateral head radiographs, changes in craniocervical posture in 11 children from 5 to 11 years, with mixed dentition and of the mandibular prognathism Class III, which is used as an orthodontic treatment with a ment prothesis, accompanied by a lower plate acetate. Although no statistically significant data obtained ( $p<0.05$ ), trends were observed during treatment, the increase of the head extension and reduction of the Cobb angle, and after four months of withdrawal of the chin cup, the column posteriorization upper cervical and lower anterior (approaching the cervical rectification).

The authors suggest that the increase in length while using the ment prothesis can be justified by postural compensation of the head and neck muscles to adapt the visual axis in space or to maintain the flow in the airways. ${ }^{(9)}$

Already Lippold et al. ${ }^{(16)}$ determined aim in his study asked if an early orthodontic treatment in children with posterior cross bite would generate negative effects on body posture. For this, they evaluated the angles of lumbar lordosis and thoracic kyphosis in addition to the lateral deviation and rotation of the spine using well, pelvic tilt and twist through the three-dimensional examination of these segments. The average time interval between the pre- and post-assessment was a year and a month, and seventy-seven children divided between control and intervention groups group (receive orthodontic treatment for posterior cross bite). The results showed no significant changes in those variables, concluding that early orthodontic treatment did not influence the body posture of these children.

Finally, Kumar and Pentapati ${ }^{(18)}$, again found no significant changes in the position of the head of patients undergoing orthodontic treatment with headgear when comparing to the control group. The group that received treatment for Class II malocclusion was composed of thirty men and were compared with 25 individuals, also men in the control group, by evaluating the facial measurements and angles collected through a sagittal cephalogram.

Based on these, we can see that only the orthodontic treatment is not sufficient for the correction of postural dysfunctions possibly generated by malocclusion. Perez et al ${ }^{(9)}$ suggests that other factors may be associated with postural changes (such as age, the type of teeth or orthodontic therapy used), and sometimes overlaps a malocclusion. Furthermore, to Kumar and Pentapati ${ }^{(18)}$, an extended posture modification during growth can lead to permanent musculoskeletal changes.

This review also includes two states that had body balance in their methods. The first, of Perinetti et al.(1), aimed to investigate whether malocclusion was correlated with postural changes in young individuals, and it used a sample of 122 young people, between 10 and 16 years with malocclusion. The anteroposterior and lateral deviations have been verified by pressure platform on two conditions: mandibular relaxation and dental intercuspation. Few data were considered significant, including malocclusion classified as overbite shown to be associated with anteroposterior and lateral changes the center of gravity body. However, significant variables considered corresponded $3-9 \%$ of the evaluation carried out, not being sufficient, according to the authors, to attest to the modification of postural stability.

The second study assessed body balance was Perillo et al. ${ }^{(13)}$, investigating the relationship between malocclusion and Helkimo Index $\geq 5$ with postural changes in 1178 young people from 11 to 19 years. The posture was analyzed by static evaluation (tilt and trunk asymmetry) and dynamic (Test of Fukuda steps, validated for balance assessment). A significant correlation was found that patients with malocclusion and Helkimo Index $\geq 5$ had worse asymmetry trunk and better performance in the Fukuda test.

These results show that individuals with malocclusion can develop a change of static equilibrium, but not significant when evaluated dynamically. Perillo et al $^{(13)}$ also assumes that the greater activation of postural muscles in these individuals 
may have positively influenced the Fukuda test, increasing their performance.

Lopes et al. ${ }^{(10)}$ evaluated the posture of 41 children, 6-12 years old, with posterior cross bite, with deciduous or mixed dentition, which had never undergone orthodontic treatment. To evaluate photographic records were carried out in front, side and back plans in order to verify the presence of asymmetries. The results showed average incidence in a total of 22 individuals, $65 \%$ of postural changes when evaluated the joint parameters: iliac crest (hip) and birotular (knees), 95\% for the parameter biacromial joint (shoulder), 63.64\% imbalance of postural changes in body axis, especially the anterior (imbalance of body axis, with projection below), $77.27 \%$ for joint gluteal folds parameters (glutes), featuring asymmetrical, $68.18 \%$ for the parameter bimalleolar (ankles), and 100\% for the parameter biescapular joint (posterior shoulder).

Aldana et al. ${ }^{(12)}$, through a cross-sectional study, sought the relationship between malocclusion and postural abnormalities of the head and neck. For this, they used a sample of 116 malocclusion patients who have undergone orthodontic treatment. Thus sought associations between craniocervical Rocabado analysis, the cephalogram and functional evaluation of the language. Among the results found weak associations statistically significant between the counterclockwise rotation skull with Class III, the mandibular posterior rotation and dolichofacial and facial individuals and Class II with the tongue position at rest.

García et al. ${ }^{(14)}$ investigated the existence of significant differences in cervical posture of 28 adolescents with dental occlusion different classes. Among the results there was a significant relationship between cervical curvature and the distance between the occipital and the first cervical vertebra to the skeletal occlusal Classes.

Deda et al. ${ }^{(15)}$ in their study, compared the position of the head in different classes (Class I, II and III) by photogrammetry and clinical inspection the sample of twenty-five patients diagnosed with malocclusion. There was no significant difference between classes and influenced malocclusion on the angle head-neck evaluated by photogrammetry. However by clinical inspection, he noticed a pattern in head position in individuals Class II, where $100 \%$ had forward head. Another significant value was observed in the control group, who did not have changes in occlusion, where $73.3 \%$ had neutral head position.

Silvestrini et-Biavati al. ${ }^{(17)}$ analyzed the incidence of malocclusion correlating with posture and disorders of ocular convergence. In a sample of 605 children, found that 93.8 to $94.2 \%$ of the entire sample, consisting of individuals with and without malocclusion presented symmetry of the lower limbs. The study also evaluated the presence of gait disturbance, which was not found significant differences between the occlusal Classes.
Kim, Sarauw and Sonnesen ${ }^{(20)}$ through radiographs in Antero-posterior plane of hundred eleven children with open bite, evaluated the cervical and facial morphology relating to head posture. The results showed that individuals with open bite the skeletal type had higher extension head to compare with the open bite group dentoalveolar type.

\section{CONCLUSION}

It concludes that malocclusion is associated with the individual's posture changes, since 8 studies among the 13 selected articles showed significant results on this relationship. Regarding the balance, we analyzed two studies, which had among its objectives associate it to malocclusion, one being considered positive for the worsening of static equilibrium, but with no clinical application, and another positive for the improvement of dynamic equilibrium.

\section{AUTHORS CONTRIBUTION}

TGS and ACOS preparation of the manuscript, HPN and CDAR preparation of the manuscript, TGS formatting the manuscript, CDAR reviewing the manuscript.

\section{COMPETING INTERESTS}

The authors declare no conflicts of interest.

\section{AUTHOR DETAILS}

2 Physical therapy professor, Universidade de Sorocaba, Sorocaba, São Paulo, Brazil.

\section{REFERENCES}

1. Perinetti G, Contardo L, Silvestrini-Biavati A, Perdoni L, Castaldo A. Dental malocclusion and body posture in young subjects: A multiple regression study. Clinics. 2010;65(7):689-95.

2. dos Reis AC, Lima ECB, Moyses MR, Ribeiro JCR, Silva LJ. Entrenamiento de postura en pacientes portadores de disfunciones temporo-mandibulares. Acta odontol. venez. 2007;45(2):302-305.

3. Amantéa DV, Novaes AP, Campolongo G D, Barros TP. A importância da avaliação postural no paciente com disfunção da articulação temporomandibular. Acta ortop. bras. 2004 Sep;12(3):155-159.

4. Bricot B. Posturologia. 2a Ed. São Paulo: Ícone; 2001.

5. McNeill C. Ciência e prática da oclusão. São Paulo: Quintessence, 2000.

6. Rizo $\mathrm{AMH}$, Cabello MA, Pozo FP, Carrasco AL. La postura del segmento cráneo-cervical y su relación con la oclusión dental y la aplicación de ortodoncia: estudio de revisión. Osteopatía Cientifica. 2010;05:89-96.

7. Kutin G, Hawes RR. Posterior cross-bites in the deciduous and mixed dentitions. Am J Orthod. 1969;56(5):491-504.

8. Artese A, Drummond S, Nascimento JM, Artese F. Critérios para o diagnóstico e tratamento estável da mordida aberta anterior. Dental Press J Orthod. 2011 Mai-Jun;16(3):136-61.

9. Pérez LJ, Gómez S, Llano E, Rivera WA. Postura craneocervical em pacientes infantiles después de la terapia com mentonera. Un estudio piloto. Revista Facultad de Odontología Universidad de Antioquia. 2009 Primer semestre;20(2).

10. Lopes JJM, Lucato A, Boeck EM, Kuramae M, Vedovello Filho M. Relação entre mordida cruzada posterior e alterações posturais em crianças. RGO, Porto Alegre. 2009 Out/Dez;57(4):413-18.

11. Marşan G, Öztaş E, Cura N, Vasfi Kuvat S, Emekli U. Changes in head posture and hyoid bone position in Turkish Class III patients after mandibular setback surgery. Journal of Cranio-Maxillo-Facial Surgery. 2010;38:113-21. 
12. Aldana PA, Báez RJ, Sandoval CC, Vergara NC, Cauvl LD, Reguera AF. Asociación entre maloclusiones y posición de la cabeza y cuello. Int. J. Odontostomat. 2011;5(2):119-25.

13. Perillo L, Femminella B, Farronato D, Bacceti T, Contardo L, Perinetti G. Do malocclusion and Helkimo Index $\geq 5$ correlate with body posture? Journal of Oral Rehabilitation. 2011;38:242-52.

14. García N, Sanhueza A, Cantín M, Fuentes R. Evaluation of Cervical Posture of Adolescent Subjects in Skeletal Class I, II, and III. Int. J. Morphol. 2012;30(2):405-10.

15. Deda MRC, Mello-Filho FV, Xavier SP, Trawitzki LVV. Postura de cabeça nas deformidades dentofaciais Classe II e Classe III. Rev. CEFAC. 2012 Mar-Abr;14(2):274-80.

16. Lippold C, Moiseenko T, Drerup B, Schilgen M, Végh A, Danesh G. Spine deviations and orthodontic treatment of asymmetric malocclusions in children. BMC Musculoskeletal Disorders. 2012;13:151.
17. Silvestrini-Biavati A, Migliorati M, Demarziani E, Tecco S, SilvestriniBiavati P, Polimeni A, Saccucci M. Clinical association between teeth malocclusions, wrong posture and ocular convergence disorders: an epidemiological investigation on primary school children. BMC Pediatrics. 2013;13:12.

18. Kumar S, Pentapati KC. Effect of low pull headgear on head position. The Saudi Dental Journal. 2013;25:23-27.

19. Kim M, Kim B, Youn J, Kim Y, Park Y. Head posture and pharyngeal airway volume changes after bimaxillary surgery for mandibular prognathism. Journal of Cranio-Maxillo-Facial Surgery. 2014;42:531-35.

20. Kim P, Sarauw MT, Sonnesen L. Cervical vertebral column morphology and head posture in preorthodontic patients with anterior open bite. American Journal of Orthodontics and Dentofacial Orthopedics. 2014 March;145(3):359-66.

21. Guedes SPC, Teixeira BV, Cattoni DM. Medidas orofaciais em adolescents do estado do Rio de Janeiro Segundo a tipologia facial. Revista CEFAC. 2010 Jan-Fev;12(1):68-74. 